\title{
PLAYERS AS PROSUMERS - HOW CUSTOMER ENGAGEMENT IN GAME MODDING MAY BENEFIT COMPUTER GAME MARKET
}

\author{
Dewalska-Opitek, A., Hofman-Kohlmeyer, M.
}

Anna Dewalska-Opitek / University of Economics in Katowice, Faculty of Informatics and Communication, Department of Organisational Relationship Management, 1 Maja 50, 40-287 Katowice, Poland. Email: anna.dewalska-opitek@ue.katowice.pl

Magdalena Hofman-Kohlmeyer / University of Economics in Katowice, Faculty of Informatics and Communication, Department of Organisational Relationship Management, 1 Maja 50, 40-287 Katowice, Poland. Email: magdalena.hofman-kohlmeyer@edu.uekat.pl

\section{Abstract}

Consumers play extra-role behaviours while actively participating in designing and improving goods and services, thus becoming prosumers. Modding, i.e. game modifications which aim at creating a new or improving experience for the players, is an interesting form of prosumption observed in the game industry. The general purpose of the study is to identify to what extent players are willing to perform game modding, as well as who and how may benefit from this extra-role behaviour. Qualitative research was conducted in the form of focus groups with Polish game players. Results of the conducted research allow identifying benefits for four groups of beneficiaries, i.e., players as mod users (game diversification, better customisation, higher quality of games, more realism of the game, fun and excitement to play a modified or a new game, prolonged games' lifespans), modders as mod creators (creativity, gaining knowledge about how to create a game, social affiliation and pride or career development) game developers (extending games' lifespans, updating, and renewing game, improving the quality of games, the opportunity to reach a wider audience) and intermediaries like cloud gaming platforms which share the benefits with game developers.

Implications for Central European audience: The study provides evidence that customers' inclination to prosume may vary and is stimulated by specific drivers in the form of perceived benefits. Thus, the research supports Adam's equity theory. From the managerial perspective, the current study provides useful, actionable guidance on how to encourage players to engage in real prosumtion in virtual worlds. Game producers need to learn about their customers' needs outside of normal exchange processes. Players shall be perceived as an inseparable part of the gaming industry, who deliver an extra value to the market by game modding activities.

Keywords: benefits; game modding; prosumption JEL Classification: M31, O35 


\section{Introduction}

The contemporary market is a dynamic and increasingly complex environment, where traditional roles of customers and producers are partly reversed and complementary. Customers are no longer a "passive audience"; they play extra-role behaviours, engage in a variety of positive, discretionary behaviours directed towards companies, and other customers (Yi \& Gong, 2006, p. 146), actively participating in the idea-sharing process or designing and improving goods and services (Prahalad \& Ramaswamy, 2004, p. 5). Various terms have been used to describe this behaviour, including voluntary customer behaviour (Balaji, 2014, p. 224; Bettencourt, 1997, p. 386; Rosenbaum \& Messiah, 2007, p. 261), customer citizenship behaviour (Dewalska-Opitek \& Mitręga, 2019, p. 49; Groth, 2005, p. 8), customer value co-creation (Agrawal \& Rahman, 2015, p. 145; Fernandes \& Remelhe, 2016, p. 313), or prosumption, which is the subject matter of general interest presented in the paper. The evolving perception of consumers' roles highlights a new perspective in which consumers can be viewed as productive players in the marketplace (Vargo \& Lusch, 2004, p. 1-2; Vargo \& Lusch, 2008, p. 3). Customers are no longer willing to buy products and services from the existing offer; they are rather interested in cooperation with producers to obtain more customised and personalised products that will satisfy their needs to a higher extent. (Bednarz, 2017, p. 8). The popularisation of new platforms and technologies within the so-called "Web 2.0" encouraged creating and sharing content.

Game modding is an interesting form of customer prosumtion. Players perform a pivotal role in the contemporary computer gaming industry. A review of emerging literature shows that most of the research has focused on the nature of prosumption and how it may benefit producers. What is absent in the debate is the consumers' perspective and the advantages of extra-role behaviour for engaged consumers and other end-users. Our study attempts to address the gap in our knowledge of customers' inclination to engage in prosumption in the form of game modding.

The general purpose of this study is to identify the inclination of customers to perform game modding as a form of prosumption in favour of companies and other game users. The following research questions were formulated: To what extent game players are willing to engage in prosumption behaviour by using or creating game modding? Who can benefit from game modding? What are the main benefits for game modding perceived by prosumers? Qualitative research in the form of focus groups with Polish game players (including mod users and mod creators) was conducted to collect information. The study provides evidence for the distinctive advantages of prosumption for all market players: gamers, producers, and intermediaries. The paper presents conclusions points at some limitations and indicates the possible future research areas.

\section{Theoretical background}

\subsection{Customers' extra-role behaviour}

The term "prosumption" is derived from "production" and "consumption" to indicate the tendency of these two aspects of an economic system to converge toward a unique value creation process. According to this concept, consumers cooperate with firms to "produce" value through their experiences and by attributing symbolic meanings to consumption. Prosumption has been related to a need for consumers to customise offerings and is 
emerging as a marketing approach. In such an approach, customers can collaborate with firms in manufacturing activities and service delivery so that they may construct their consumption experiences and create value with firms (Prahalad \& Ramaswamy, 2004, p. 7). Based on a psychological approach, Xie et al. (2008, p. 109-122) deemed prosumption as the set of value creation activities that consumers perform to contribute to the production of products and services they eventually consume. Customer performance is consciously directed to increase the value of the product and process of usage.

Prosumption is similar to other practices such as co-production and co-creation. All of these practices involve a degree of participation on the part of the consumer (Humphreys \& Grayson, 2008, p. 965-968) as an integrator of resources who can produce value alone or through participation with other players (i.e. companies or/and other consumers) (Vargo \& Lusch, 2008, p. 5). Nonetheless, Alhashem et al. (2013, p. 149) argue that prosumption is different from other consumer co-creative practices since it revolves around consumers' ability to produce products for their own use, rather than the use of others. Such distinction may help to clarify the potential areas of participation among and between consumers and producers in terms of how co-creators and prosumers integrate resources and produce value. Wolf and McQuitty (2011, p. 154-170) suggest that prosumption requires more involvement from consumers than co-creation or co-production. The authors argue that co-creation and co-production assume that consumers take partial responsibility for some tasks typically undertaken or proposed by the company, while prosumption assumes that consumers take full responsibility for the conception and production of their own products and services.

By contrast, Bruns (2008) introduces the concept of produsage as an explicit alternative to prosumption. The formulation of this term is a combination of "production" and "usage" and is designed to emphasise the inherent role of potential participants in produsage as active users of content and information.

Consumers may play extra-role behaviours to various extent. Etgar (2008, p. 100) proposed a conceptual model in which presumption is deemed to be a dynamic, five-stage process (see Fig.1)

Figure 1 | Prosumption as a dynamic process

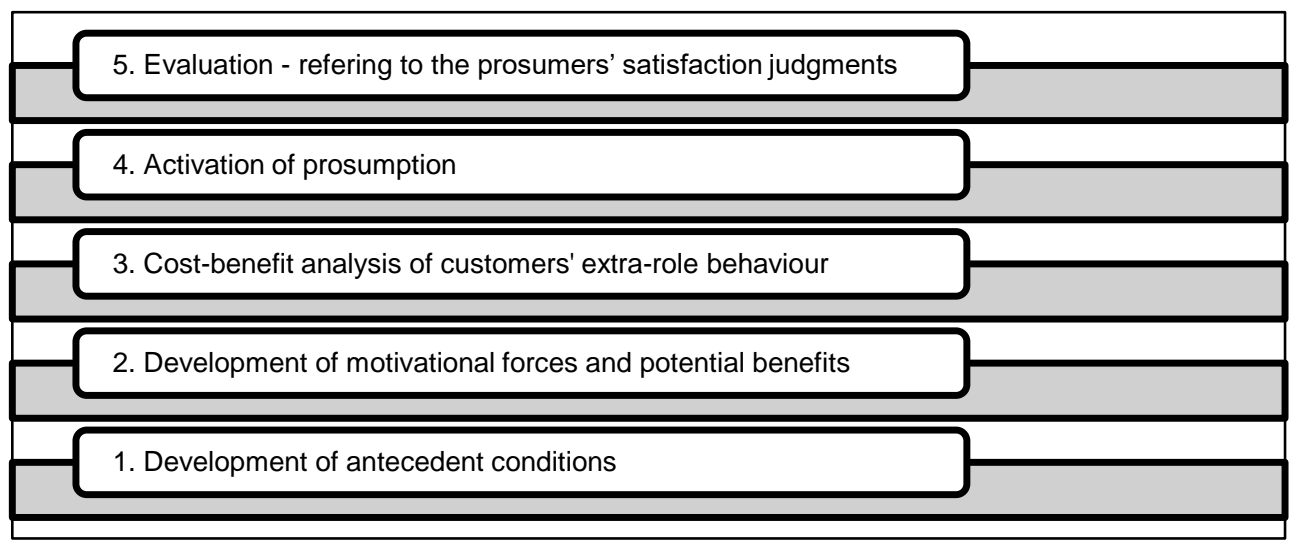

Source: Etgar (2008, p. 100) 
The first phase is the development of antecedent conditions, which are specific to the environment, the customer, the product, and the situation characterising the contextual interaction between a firm and its customers. The second phase regards the development of motivational forces. These may be economic drivers (such as cost reduction), psychological motivations (such as personal values and desires), and benefits associated with the interaction. The third phase deals with a cost-benefit analysis that customers would perform before deciding to prosume. The fourth phase regards activation, at which customers choose (or are allowed) to collaborate with firms, thus becoming prosumers. Customers may participate in several phases of the production and value creation process. They may intervene in product initiation and design, information delivery for customising a product or a service, manufacturing in a strict sense, through the construction, through participation as self-assemblers of single pieces of a product and self-deliverers, and consumption, through participation as co-creator of symbolic meanings and experiences (Payne et al., 2008, p. 86). The fifth phase regards evaluation and refers to the prosumers' satisfaction judgments (Guido \& Peluso, 2008, p. 67).

Forms of prosumption may vary, depending on customers engagement and the extent to which companies are willing to adopt the extra-role behaviours. Examples of prosumption encouraged by selected firms are presented in Table 1.

Table 1 | Illustrative examples of companies adopting prosumption

\begin{tabular}{l|l}
\hline Company & Brief description of the strategy \\
\hline Apple & $\begin{array}{l}\text { Customers can share their evaluations based on consumption experiences through an } \\
\text { online recommendation system. }\end{array}$ \\
\hline Audi & $\begin{array}{l}\text { Customers can discuss and provide } \\
\text { evaluations and suggestions about both established and new products. }\end{array}$ \\
\hline Diesel & $\begin{array}{l}\text { Customers can build their own Audi car } \\
\text { on the corporate website by selecting preferred product features from among among a set } \\
\text { of available options. }\end{array}$ \\
\hline Ikea & $\begin{array}{l}\text { Customers are offered several interactive initiatives that help them personalise their } \\
\text { consumption experiences. }\end{array}$ \\
\hline Nike & Customers can transport and assemble their products by themselves. \\
\hline Pastificio Rana & $\begin{array}{l}\text { Customers can send online their own recipes to be considered in new product } \\
\text { development. }\end{array}$ \\
\hline Procter \& & Customers can select specific characteristics of certain products (e.g., coffee aroma). \\
\hline Gamble & $\begin{array}{l}\text { Customers are offered several interactive initiatives that help them personalise their } \\
\text { consumption experiences and share opinions constructively. }\end{array}$ \\
\hline
\end{tabular}

Source: Guido and Peluso (2008, p. 70)

Literature studies allow identifying various types of prosumption. According to Mitręga (2016, p. 8), there are two types of prosumption to be distinguished, i.e., exhibitionistic and rationalising. Both types of prosumtion allow to increase the value of a good or a service purchased by consumers, but still, significant differences may be observed. Exhibitionistic prosumtion is characterised by consumers' desire to achieve symbolic or real benefits by product customisation and may be reflected in customers' participation in testing new products or spontaneous sharing of opinions on goods and enterprises, for example, in social 
media. On the other hand, rationalising prosumption focuses on minimising costs associated with the purchase and/ or usage of goods by consumers. This type of prosumption may be manifested in activities traditionally performed by companies, like packaging or transporting goods or using their own product modification, such as replacing branded ingredients with cheaper substitutes.

Roberts et al. (2013, p. 151) identified other types of customer extra-role behaviours, i.e., independent customer innovating and joint innovation activities, among others. A similar prosumption typology was proposed by Wittmayer et al. (2019, p. 18), who pointed at individual and collective prosumption. The typology takes into consideration whether individual prosumers connect with communities through their practices, which in turn enables wider social impact and tighter social relationships.

It should be noticed that prosumtion, as an extra-role behaviour, requires an investment of resources by consumers or a sacrifice (such as time and effort) on customers' part, which is sometimes described as commitment or supportive behaviour (Wing Sung Tung et al., 2017, p. 23-35). Consumers, therefore, may expect certain benefits that would reward their engagement. Two questions may, therefore, arise: who may benefit from prosumtion and what are the benefits of prosumption? Addressing these questions requires the consideration of related concepts and theories relevant to the subject matter.

Using consumers as co-creators of value, the company utilises them as operant resources in the firm's innovation process (Xie et al., 2008, p. 109-122), making use of their skills, knowledge, and creativity. Nevertheless, there are many parties to benefit from prosumption:

- $\quad$ The prosumers who are willing to provide extra role behaviour (Dewalska-Opitek \& Mitręga, 2019, p. 51).

- Other consumers, who take advantage of product or service improvements, higher quality level, better usability, etc. (Holbrook, 2006, p. 718).

- The company, which is the most apparent beneficiary - due to prosumption, the value of a product or a service is improved much earlier than if the creation of value was left solely to the firm; thereby, it enhances marketplace acceptance and product longevity (Guido \& Peluso, 2008, p. 67; Roberts et al., 2013, p. 152).

According to Alhashem et al. (2013, p. 149-151), individual (personal) benefits of prosumtion may consist of functional, hedonic, and cognitive ones. Functional benefits refer to monetary savings or prosumers' self-sufficiency (e.g. fixing goods DIY projects to save time and money). Prosumers' experiences contribute to functional benefits through developing cheaper, better, or more environmentally friendly products (which may be referred to as environmental benefits of prosumption). Cognitive benefits of prosumption refer to how prosumers feel or think because of their prosumption activities (e.g. gaining or developing problem-solving ability, gaining experience and knowledge). Hedonic benefits are consistent with the driving purpose of entertainment value, enjoyment, and fun. In addition to the personal benefits of prosumption, there are other benefits on the social (collective) level. They refer to the advantages which are often contributed by prosumers to other users (the society). Such benefits encompass developing products for family, friends, and other users, contributing to their communities and domains in the market and the environment. Alhashem et al. (2013, p. 151) argue, that prosumers usually associate their extra-role behaviour with non-market-based benefits. However, some prosumers gain some economic benefits from 
their prosumer activities (buying goods or services delivered to the market by their peers). The above-mentioned benefits of prosumption may be presented in a model (see Fig. 2).

Figure 2 | Benefits of prosumption according to Alhashem

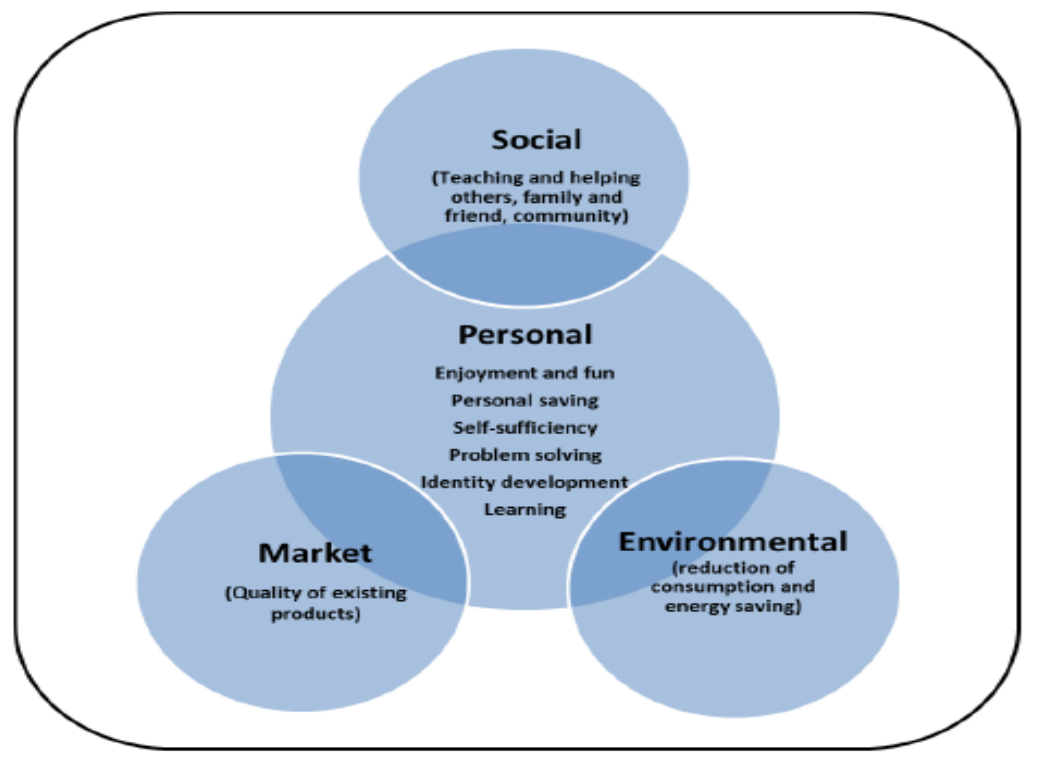

Source: Alhashem et al. (2013, p. 151)

Steen et al. (2011, p. 57-58) states that many businesses and organisations expect a wide range of benefits from prosumption as customers extra-role behaviour. The authors divided the benefits into categories, pointing at benefits for organisations and benefits for (innovative) projects they develop. Brief characteristics of the business-oriented benefits is presented in Table 2.

\section{Table 2 | Business-oriented benefits of prosumption}

\begin{tabular}{ll}
\hline Benefits for organisations & Benefits for (innovative) projects \\
\hline Improved creativity & $\begin{array}{l}\text { Better ideas (e.g. from customers or users with } \\
\text { Improved focus on customers or users, e.g. }\end{array}$ \\
$\begin{array}{l}\text { high originality of user value) } \\
\text { better dissemination of knowledge about }\end{array}$ & $\begin{array}{l}\text { together customers, users, and employees } \\
\text { customers' and users' needs }\end{array}$ \\
$\begin{array}{l}\text { More successful innovations } \\
\text { Improved innovation practices, processes, and }\end{array}$ & More differentiated service \\
capabilities & \\
Better relations with customers and users & \\
Lower costs & \\
Better knowledge about customers' and users' \\
needs
\end{tabular}

Source: Steen et al. (2011, p. 57-58) 
Prosumers may be willing to perform their extra-role behaviour due to the various benefits they (and other market players, i.e. other users, and businesses) obtain from the activity. Also, other users and companies take advantages of prosumption to various extent, eagerly participating in this collaboration. An explanation of this phenomenon may be found in the theory of motivation; the adaptation of Adam's theory of equity focuses on determining whether the distribution of resources is fair to each of the relational partners. Equity is measured by comparing the ratio of contributions (or costs) and benefits (or rewards) for each party (Ross \& Kapitan, 2018, p. 529-530).

\subsection{Game modding as an emerging trend of prosumption in the gaming sector}

Game modding is an interesting form of prosumtion presented in this paper. It is an umbrella term describing a variety of activities, ranging from user-generated content (UGC), in which users forward content made by others, to user-created content (UCC), in which the content is made by the user (Hinton \& Hjorth, 2013, p. 55). Content creation can be anything from slight changes in how the virtual world is presented to critical innovations that rend the game anew with surroundings, narrative, and characters (Postigo, 2007, p. 301). More specifically, these changes are redesigns of textual codes that often maintain the structural base coding but provide a new visual context.

According to Scacchi (2011, p. 2), modding, the process of developing game mods (modifications), is typically a "do it yourself (DYI)" approach to end-user game software engineering that can establish both social and technical knowledge for how to innovate by resting control over game design from their original developers. Modders introduce changes to already existing games. However, in extreme cases, modders remove almost the entire original content of the game and create a completely new one. This action is known as "total conversion modding" (Wallace, 2014, p. 220-221).

Game modding requires advanced skills, from programming, video making, sound recording to graphic editing. The vast part of creators collaborate in small teams, learn important skills, help one another, and form a community (Loh \& Byun, 2009, p. 410). A standard large modification for a top action-adventure game was estimated to take over 1000 hours of work per one creator and collectively for a team approximately 39000 working hours. A group of game content producers is named "user/developer community" or "modding community" (Poretski \& Arazy, 2017, p. 480). Modding communities are also helpful to independent creators by distributing their work amongst community members, gaining feedback and advice (Nardi \& Kallinikos, 2010, p. 174-186).

Literature studies allow for identifying various types of game mods. Unger (2012, p. 512) divided game mods into mutators/tweaks, add-ons, mods, and total conversions. Short characteristics of the identified types of modding activities are presented in Table 3. 
Table 3 | Types of game mods

\begin{tabular}{l|l}
\hline Construct & Operationalisation \\
\hline Mutators/tweaks & $\begin{array}{l}\text { modify limited aspects of the game, e. g. changing the game's } \\
\text { speed, adding/modifying some game rules, changing the weather } \\
\text { conditions, or implementing the option to listen own mp3 collection } \\
\text { while playing }\end{array}$ \\
\hline Add-ons & $\begin{array}{l}\text { provide some extensions to game, e. g. new maps, new units, new } \\
\text { skins }\end{array}$ \\
\hline Mods & $\begin{array}{l}\text { manipulate the rule system, the visual layer, change the original } \\
\text { game, narration, rules, and mechanism in a significant way }\end{array}$ \\
\hline & $\begin{array}{l}\text { manipulate the original game in the way that a new game is created, } \\
\text { includes a complete replacement of the visual/audible game content } \\
\text { Total conversions }\end{array}$ \\
\hline
\end{tabular}

Source: Unger (2012, p. 512)

Scacchi (2011, p. 65-68) describes the following groups of mods: user interface customisations and agents, game conversions, machinima and hacking closed game systems.

User interface customisations and agents gather mods that improve the game experience and are supported by game developers. There are three types of interface customisations. The first and most common is the player's ability to select, attire or accessorise a player's ingame identity. The second is for players to customise the colour palette and representational framing borders of their game display within the human-computer interface, much like what can also be done with Web browsers and other end-user software applications. The third is user interface add-on modules that modify the player's in-game information management dashboard but do not modify the underlying gameplay rules or functions.

Game conversions are the most popular type of game modifications. Such conversions are partial, in the way that they add or modify: in-game characters including user-controlled character appearance or capabilities, opponent bots, cheat bots, and non-player characters; game objects like weapons, potions, spells, and other resources; game levels, zones, maps, terrains, or landscapes; game rules; or game mechanics. Some more ambitious modders go as far as to accomplish total conversions that create entirely new games from existing games of a kind not easily determined from the original game.

Machinima can be viewed as the product of modding efforts that intend to modify the visual replay of game usage sessions. Machinima employs computer games as their creative media for some other purpose (e.g., creating online cinema or interactive art exhibition). Machinima focuses attention on playing and replaying a game for the purpose of storytelling, movie making, or retelling of daunting or high-efficiency gameplay/usage experience.

Hacking a closed game system is not focused on how to improve the game itself but rather on understanding how the game works and how the game platform is designed. In this case, mod creators cannot have any support from the game developer because game developers try to prevent modding activities (Scacchi, 2011, p. 65-68). 
Players present various inclination to engage in prosumtion in the gaming sector, due to various benefits they may experience. Potential benefits enhancing the online players' inclination to engage in prosumption among game players were proposed by Koo et al. (2007, p. 40-41). They are presented in Table 4.

Table 4 | Benefits for modding as a form of prosumption

\begin{tabular}{l|l|l}
\hline Construct & Operationalisation & Sources \\
enjoyment & $\begin{array}{l}\text { The extent to which the activity of participating in } \\
\text { modding as a mod user or a creator is perceived to } \\
\text { be pleasurable, exciting, enjoyable, fun. }\end{array}$ & $\begin{array}{l}\text { Moon and Kim (2001); Ghani } \\
\text { and Deshpande (1994); Chou } \\
\text { and Ting (2003) }\end{array}$ \\
\hline Escape & $\begin{array}{l}\text { The extent to which modding is perceived to be a } \\
\text { relief of boredom and an escape from routine }\end{array}$ & $\begin{array}{l}\text { Bloch et al. (1994); Wood et } \\
\text { al. (2004) }\end{array}$ \\
\hline Curiosity & $\begin{array}{l}\text { The extent to which the activity of modding is } \\
\text { perceived to be an experience of learning about } \\
\text { new things, strategies, and trends about online } \\
\text { game playing }\end{array}$ & $\begin{array}{l}\text { Moon and Kim (2001); } \\
\text { Griffiths et al. (2004); Bloch et } \\
\text { al. (1994) }\end{array}$ \\
\hline $\begin{array}{l}\text { Social } \\
\text { affiliation }\end{array}$ & $\begin{array}{l}\text { The extent to which the activity of modding is } \\
\text { perceived to be enjoyment of talking to and } \\
\text { socialising with other online game players }\end{array}$ & $\begin{array}{l}\text { Griffiths et al. (2004); Rohm } \\
\text { and Swaminathan (2004); } \\
\text { Bloch et al. (1994) }\end{array}$ \\
\hline $\begin{array}{l}\text { Recognition } \\
\text { and } \\
\text { appreciation }\end{array}$ & $\begin{array}{l}\text { The extent to which the activity of modding allows } \\
\text { to gain other players' recognition and appreciation } \\
\text { and is a form of reward for the extra-role behaviour }\end{array}$ & $\begin{array}{l}\text { Moon and Kim (2001), } \\
\text { Webster et al. (1993), } \\
\text { Koufaris (2002); Chou and } \\
\text { Ting (2003) }\end{array}$ \\
\hline
\end{tabular}

Source: Koo et al. (2007, p. 40-41)

The presented benefits of enjoyment and escape were derived from the concept of flow. The flow concept is defined as the state in which people are so intensely involved in an activity that nothing else seems to matter; the experience itself is so enjoyable that people will do it even at great cost, for the sheer sake of doing it. Epistemic curiosity is the extent to which the activity of playing an online game is perceived as providing learning experiences about new things, strategies, and trends about online game-playing (Moon et al., 2001, p. 226). In this respect, Griffiths et al. (2004, p. 89) demonstrate that online game players crave for new information about team-building skills, learning and thinking, upgrading their skills, developing strategies for the game, and enhancing problem-solving skills. Social affiliation is defined as the extent to which the activity of playing an online game provides enjoyment as a result of socialising with other online game players. Social collaboration among members is important in achieving complex goals and advancing in the game (NG Brian \& Wiemer-Hastings, 2005, p. 111). According to Griffiths et al. (2004, p. 90) online games have a social dimension through the formation of online communities, allowing them to gain recognition and appreciation from other players.

In the context of the present study of online games, the above-mentioned benefits might be the salient driving factors of modding. 


\section{Research methods}

The purpose of the study was to identify the inclination of customers to perform game modding as a form of prosumption in favour of companies and other game users. The following research questions were formulated:

1. To what extent are game players willing to engage in prosumption behaviour by using or creating game modding?

2. Who can benefit from game modding?

3. What are the main benefits for game modding perceived by prosumers?

Data collection was accomplished through a method of qualitative research in the form of focus groups. The research in question was conducted between December 2019 and April 2020 on Polish game users who declared having used or created mods. There were 54 participants of 6 focus groups, each of them composed of 8 to 12 participants: mod users (a dominant part) and mod creators.

The sampling method may be described as purposeful (Miles \& Huberman, 1994, p. 27). According to Morse (1994, p. 129), the purposeful sample is one of four types of sampling used in qualitative research, among the nominated sample, the volunteer sample and the sample that consists of the total population. The purposeful sampling is directed by a desire to include a range of variations of the phenomenon of the study (Coyne, 1997, p. 628) and is similar to the type of sampling called "phenomenal variation" described by Sandelowski (1995, p. 181-82) as "decision often made a priori in order to have representative coverage of variables likely to be important in understanding how diverse factors configure as a whole". In the research in question, the Authors interviewed informants with a broad general knowledge of modding and whose experience is considered typical (i.e. easily available mods' users). Then, as the study progressed, more specific information was gathered from participants with particular knowledge (modders searching for advanced mods). Finally, participants with atypical experiences were sought (i.e. mod creators), so that the entire range of experiences and the breadth of the concept of the phenomena could be understood. The described process was suggested by Morse (1994, p. 129) and followed by Coyne (1997, p. 628). According to Guest et al. (2006, p. 59) purposive sampling is the most commonly used form of non-probabilistic sampling, and its size typically relies on the concept of saturation, i.e. the point at which no new information or themes are observed in the data. More than 6 interviewed focus groups would follow similar patterns, and another interview would not provide any new information about the research problem.

The participants in the research were mainly men, using mods more often then creating them, aged 20 to 26, with secondary or higher education. Table 5 illustrates the sample characteristics.

The research was exploratory in nature, conducted to determine the nature of the problem, and was not intended to provide conclusive evidence but to have a better understanding of the problem (Henson \& Roberts 2006, p. 403). It allowed for becoming familiar with game players' opinions and attitudes towards the process of prosumption and benefits arising from game modding. Although the study lacks stochastic confirmation, the focus groups provide a qualitative method of data collection and thus does not require statistical confirmation. 


\begin{tabular}{|c|c|c|}
\hline \multicolumn{2}{|l|}{ Specification } & Sample (in \%) \\
\hline 1. Gender & $\begin{array}{l}\text { a. Male } \\
\text { b. Female }\end{array}$ & $\begin{array}{l}85 \\
15\end{array}$ \\
\hline 2. Age & $\begin{array}{l}\text { a. } 20-23 \text { years } \\
\text { b. } 24-26 \text { years }\end{array}$ & $\begin{array}{l}92 \\
8\end{array}$ \\
\hline 3. Education & $\begin{array}{l}\text { a. Primary and junior high school } \\
\text { b. Vocational } \\
\text { c. Secondary } \\
\text { d. Higher }\end{array}$ & $\begin{array}{l}- \\
- \\
76 \\
24\end{array}$ \\
\hline 4. Form of $\mathrm{g}$ & $\begin{array}{l}\text { odding } \\
\text { a. Mod users } \\
\text { b. Mod creators }\end{array}$ & $\begin{array}{l}83 \\
17\end{array}$ \\
\hline
\end{tabular}

Source: authors

According to Poovey (1995) "[...] there are limits to what the rationalised knowledge epitomised by statistics can do". Qualitative research can draw strong attention, specifically the competency, to encirclement both verbal and non-verbal behaviour, to penetrate fronts, reveal denotations and find the delicacy and difficulties (Gephardt, 2004, p. 454-462) Focus groups found applications in previous research concerning computer games. In 2011, Guo \& Barnes investigated factors influencing purchase behaviour in virtual worlds (Guo \& Barnes, 2011, p. 77). Guo and Barnes decided on a semi-structured interview format to allow participants to comfortably express their beliefs, opinions, and experiences. They also prepared a discussion guide which consisted of several sections, from introduction questions, questions exploring the goal of the study, to the summary of the interview (Guo \& Barnes, 2011, p. 81).

In the present study on modding activities of game users, the authors also employed semistructured focus groups interviews and divided the discussion into four parts. In the introduction, the study participants were asked general questions on how long they had played and what kind of computer games they had played. Then, players were asked about having used official add-ons offered by game producers. Further questions were focused on perceived benefits for using or creating game mods. The discussions ended with summaries.

\section{Research findings}

\subsection{General information on game modding}

All the researched participants were familiar with game modding, and most of them declared using mods while playing online games (83\%-45 participants altogether), while $17 \%$ (9 respondents) confirmed creating game mods.

All studied participants stated they had been playing online games for a long time: "for ages", "since I was 11 years old", "since I was a teenager", "a half of my life". Asked about the games they play, the respondents mentioned Massively Multiplayer Online Games as the most popular ones (including titles such as Matrix Online, World of Warcraft, Star Wars Galaxies Everquest, League of Legends or Guild Wars), First-person shooters (Counter Strike, Halo 
2, Quake 4 or Battlefield), Arcade games (Pac Man), Action and adventure games (The Witcher, The Legend of Zelda, God of War, Tomb Raider, The Sinking City), Strategy games (Battle for the Galaxy, Warhammer 2, Company of Heroes), Sport Games (Pro Evolution Soccer, FIFA), Simulation games (Euro Track Simulator, The Sims) and others.

After the introductory part, the participants were asked about having used any official addons. They all declared they often used them when they were available because they extended the game, made it more diversified, added new topics and plots to the old game ("same of the add-ons are like a new game, so they make a huge difference", "significantly prolong the game's life span, giving it a revival, making the game back in fashion again") or even offered corrections to some game errors

The respondents also mentioned that not all game producers provided players with the official add-ons. If not, they often searched for unofficial ones. Although some of the studied players act ethically ("am I the only person paying for the games and add-ons? I want to play legally to support the game producers"), many of them are eager to use modes to "improve how the game runs", "enhance the game graphics", "making changes to the text, for instance choosing a language that is not officially available".

It was noticed that game producers presented different attitudes towards unofficial mods created by game users - they covered the whole spectrum from penalising each mod users who decided to download any mod ("I was once banned after the game upgrade, the mods I downloaded were found I could not play for some time, even if I did not introduce any significant amendments to the game, I just changed the colour of hair of my game character") to providing the modders with game codes ("some game producers offer a regular game and they hope modders can make it better. Minecraft is a good example. Nobody would play it if there were no mods to it. But now, the producer does not have to do anything, introduce any changes to the game, there are so many good mods, the producer could not offer anything better"; "sometimes a mod turns to be a new, catchy game. As far as I know Counter Strike was a mod to Half Life, and now it is immensely popular").

The studied modders were asked about the perceived benefits and presented a wide range of them. First, the participants of the study identified the main groups of modding beneficiaries, i.e., players, modders, and companies - game developers and intermediaries.

\subsection{Main perceived benefits for players}

As modding serves improving the gaming experience, players seem to be the most relevant and evident beneficiaries. Due to mods, they gain:
a. game diversification,
b. better customisation,
c. higher quality of games,
d. more realism brought into the game,
e. fun and excitement to play a modified or a new game, as mods may significantly prolong the games' lifespans.

One of the frequently mentioned game modding benefit is the possibility of game diversification. Respondents play their favourite game, and after some time, they know the game well enough to need some changes ("mods often appear when the game starts to be boring, no longer interesting to us and then we are looking for mods to make it more exciting"). 
Due to mods, players also obtain new elements of a game, not available in the basic version: "with the help of modifications we add functionality that has not been added by the game developers, the best example is the modification that adds multiplayer to the Truck Simulator game series", "there are modifications to The Sims game series where you can choose outfits, e.g. Nike products, and this is not commonly available." Usually, mods change some part of the virtual world ("altered gameplay in terms of the appearance of the game and offered functionalities"), but in some cases modding activities allow to change the majority of content, and players gain almost completely new game ("it's quite boring to play all the time in the same game, so I just installed this mod, and it is a completely different game now, only the concept remains the same").

Prosumption increases product customisations and adapting the company's offer to the needs of a specific buyer. In terms of game modding, players adjust the product, i.e. a computer game, to their personal expectations ("mods allow customise the game to how we like it, e.g. darken a shade of armour or change what the character looks like. For example, in The Witcher we do not have many options to choose the appearance of the character, and you can install a modification that changes Gerald's hair colour").

Respondents noticed that mods are also utilised to improve the quality of the game ("sometimes fixing errors that were in the original game"). According to players, errors in the original version of games are common problems, and mods are a popular solution: "less people get discouraged when there are mods available and they fix some failures or shortcomings of the game".

The diversification and making constant changes in game content is related to another benefit from the player's perspective. Game modifications allow extending the time of playing a favourite game ("thanks to the fact that there are mods, the game is different, more exciting and we can play it longer", "a good example is well known Minecraft - without modifications that many modders offer, this game would not exist any longer, for sure").

Due to various modifications, games become more realistic. To bring more realism to the virtual environment, players often use real-life brands, for example: "You enjoy playing GTA, because you feel like in real life - for example, car brands in GTA are not fictitious but real", "the best examples are modifications to the GTA San Andreas game or any GTA games, where we can add actual existing car brands, petrol station brands or anything that increases immersion, but the modifications are not commercials, they are created by modders for other users". It can be noticed that game realism plays a significant role in simulation games ("Sims are a simulation of real life, if you play The Sims and want to create a character, you need for example clothes, so you use mods that allow the use branded clothes").

Commonly mentioned benefit of modding was the perceived enjoyment ("it is enjoyable to play a game I like, with mods even more enjoyable", "because I like playing this game, with mods there is more fun!", 'it is interesting to play something new"). It can be observed, that fun and excitement of game modding were shared by both mod users, and mod creators ("for fun", "it is exciting, when you can. It feels good when you are capable of creating a mod, on the other hand it is much easier to create a mod than a new game from the scratch", "It is great, when the game producer applies your mod in the game"). 


\subsection{Perceived benefits for mod creators}

Modders also pointed at other benefits achieved of mods creation, i.e.:
a. creativity,
b. gaining knowledge of how to create a game,
c. social affiliation and pride,
d. career development.

For many respondents, game modding is a way to increase their natural creativity ("I like creating something new", "yes, the creativity and inventiveness that are developed by making mods", "people can use their talents"), and learn how to create and design games. According to the research subject, developing mods may be easier than producing a whole game ("it is a learning experience", "you can learn something new using tools shared by others, and then when you become better, more fluent and proficient, you can create your own games, completely new ones", "when you think of making games it is good to start with mods first" , "it is a nice thing you can start with"). It is important that new creators can count on community support.

Game modding also gives an opportunity to present the modder's skills ("It seems to me that there is a general interest in creating games and a desire to share one's work with the community", "you can help yourself and others to experience greater fun by playing a game with mods"). Modders like being creators, and they want their work to be recognised and appreciated. They used various platforms related to computer games to share their creations and get positive feedback ("there are websites, where modders are associated, you can upload a file with a mod, and the community evaluates the mod based, and then it is recommended and everyone starts downloading it'). After they are presented to the community, mods can get a high status or be ranked on modder community sites, get shared and bring glory to the modder ("and then the great feeling when your file is displayed, and people start downloading it').

Game modding experience can be the first step in the gaming industry ("A lot of people made a career using only the skills they have acquired by programming or creating mods, especially for games that did not support mods", "I think that the modders train themselves doing such things, because I watched interviews with game developers and many of them started by being modders"). The knowledge and skills acquired during modding are helpful in applying for a job ("I would say that creating mods taught me how to design games, and maybe in future it would be helpful in getting a job"). The opportunity of getting a job in the gaming industry is an important benefit. However, when asked about the financial benefits of game modding, respondents declared that very few modders would earn money on modding: "The reason for creating mods is usually bottom-up, e.g. to improve a game, join some communities, not top-down. Corporations do not pay for this. Why should they? There are others, who can do it for free").

\subsection{Perceived benefits for companies - game developers and intermediaries}

The third group of beneficiaries mentioned by the respondents were game developers. Among the main advantages of game modding, the following were identified: 

a. extending games' lifespans,
b. updating, and renewing game,
c. improving the quality of games,
d. the opportunity to reach a wider audience,
e. unpaid work (value) delivered by game modders.

From the game developers' perspective, the main benefit of game modding is extending a lifespan of a particular game ("If you don't want to play a game any longer, you became familiar with it, there is nothing exciting about it, a modification can make you play it over and over again, it looks like a completely new game"). The longer a game is in the market, the more profits it offers to the developers ("there are games that still exist in the market only because of mods are available, a great example can be Heroes 3 or Minecraft"). Mod creators also update and renew existing games and increase their quality of games ("I suspect that without mods many people would simply be disappointed with games. They would not only get bored quickly, but simply be disheartened by errors and deficiencies, such as a poor interface"). All the mentioned modding advantages improve the game user experience, increase satisfaction, and prolong games' lifespans.

An interesting topic was raised during focus group interviews. Researched modders stated that skilled players deliver unpaid work to game developers, who take advantage of all the improvements introduced to the games by amateurs ("game producers do not seem to be bothered by mods, but they willingly introduce them in new versions of games later on", "they get real benefits based on the fact that when they see that a mod has really great support from players and the whole game community, they extract some fragments from this modification, steal some ideas - so to say - and include them in games as updates or subsequent versions").

As far as gaming companies are concerned, the researched participants pointed at intermediaries as beneficiaries of mods. The intermediaries are cloud gaming platforms from Microsoft (xCloud), Google (Stadia), or others (G2A), platforms with innovative gaming models. They become a global digital marketplace offering games by the use of redemption keys. Platforms do not purchase or sell any digital products themselves; they connect the buyer to the seller ("It is about a business model. If you are looking for a relatively cheap game, you can choose G2A. It is a company offering game key codes to such platforms as Steam, Origin, Uplay, PlayStation Network and Xbox".) Similarly to producers, mods prolong interest of games offered by the intermediaries.

\section{Discussion}

Game modding is undoubtedly an emerging trend, changing the gaming industry. Literature studies, as well as results of the conducted research, allow for noticing that customers are an inseparable part of the gaming market. They play active roles of prosumers and deliver an extra value to the market by game modding activities. Of course, the scope and level of their engagement may differ, which brings the answer to the first of research questions about the extent to which game players are willing to engage in extra-role behaviour by using or creating game modding. Mods users not only utilise mods but also comment on them, providing feedback to mods creators, recommend mods to other game players, and share. Highly engaged customers go one step forward and create mods, offering extra value to the game, game developers, intermediaries, and other players. Creating mods requires extra 
knowledge and skills, time, and effort (Van Doorn et al., 2010, p. 159). Not every game player is willing and able to create mods. A general supposition may arise that game players are eager to use, recommend or even create mods. Prosumption may be considered as an important manifestation of customer engagement (Fernandes \& Remelhe, 2016, p. 313), and the level of engagement differs from mods users to mods creators.

Results of the conducted research allowed to identify the following beneficiaries of game modding, i.e.: players (mod users), modders (mod creators), and companies (game developers and intermediaries). This conclusion allows answering the second research question. Consumers and producers are quite evident entities taking full advantage of game modding (Kretzschmar \& Stanfill, 2019, p. 519-520; Wallace, 2014, p. 219-222), but intermediaries are not commonly recognised but significant beneficiaries and should be taken into consideration in theoretic deliberations and further research.

In response to the third research question, a variety and heterogeneity of benefits was discovered, which derive from game modding as a prosumption activity. Referring to Alhashem's model of prosumption benefits (Alhashem et al., 2013, p. 151), three categories were empirically confirmed, i.e.:

a. Social (collective) benefits, mainly related to mod users (helping others to obtain higher game functionality and quality), but also game modders (social affiliation by participating in a modding community).

b. Personal (individual) benefits, such as increased creativity, gaining knowledge about how to design a game, modders' pride or career development. They are generally related to benefits obtained by game modders.

c. Market benefits, such as game diversification, better customisation, higher quality of games, more realism brought into games, and prolonged the games' lifespans. These benefits are shared by developers, intermediaries, and players.

Similar benefits were noticed and described by Wallace (2014, p. 219-222), Kretzschmar \& Stanfill (2019, p. 519-520) or Poretski et al. (2019, p. 2-3).

While referring to the consumption value theory introduced by Sheth et al. (1991, p. 159165), Kim et al. (2002, p. 307-308) present an opinion that modders create or utilise any user-generated content because they are driven by specific values, i.e., functional (influencing the game functionalities and ensure the higher quality), emotional (excitement, pride) and social ones (helping others, positive contribution to a gaming community).

Literature studies and conducted research allow us to draw a conclusion that consumers' inclination to perform an extra-role behaviour (like game modding) to a great extent depends on expected benefits. It may be referred to and explained by Adams theory of equity (Guerro et al., 2011, p. 263). Prosumers are eager to sacrifice their time, knowledge, and skills if they are rewarded accordingly (by obtaining desired benefits).

An interesting topic of unpaid work (value) delivered by game modders in favour of game developers (but also intermediaries) arose while discussing with research participants. This type of work, mainly associated with gaming culture, is often referred to as "playbour" (Kücklich, 2005, p. 1-3; Törhönen et al., 2019, p. 2559). The term means a type of free labour that fits neither traditional definitions of work nor the categories of play or leisure; it is rather a combination of both. The basis for this type of labour relies on the prosumption of any content in digital formats, which is considered to generate value through, e.g. modding. 
Although the commodifying or exploitative nature of this labour is a constant discussion among scholars (Fuchs, 2013, p. 101-105; Terranova, 2013, p. 35-37), some have argued that the prosumption culture, as well as the development of the digital economy, has given the free labour a market value (Hong \& Chen, 2014; Törhönen et al., 2019, p. 2559). It may be observed that the distinction between play and work is so evident in the gaming industry.

\section{Conclusion}

To summarise it, consumers play extra-role behaviours while actively participating in designing and developing games and becoming prosumers. An interesting form of prosumption observed in the gaming industry is modding, i.e. game modifications which aim at creating new or improving existing experience to the players. This research suggests that customers' inclination to engage in modding varies from mod using to mod creating and depends on their skills, knowledge, and perceived benefits: personal, social and market benefits. The study also identifies the main beneficiaries of game modding, i.e., mod users, mod creators (as customers), game developers and intermediaries (as companies operating on the gaming market). Intermediaries are not usually mentioned when beneficiaries of modding are discussed in the literature.

The study may enrich our understanding of customers' inclination to engage in modding on both theoretical and managerial levels. This study provides tentative evidence for perceived benefits, which are the key drivers for prosumtion in the form of game modding. The research supports Adam's equity theory; prosumers are eager to sacrifice their time, knowledge, and skills if they are rewarded accordingly (by obtaining desired benefits). On a managerial level, the current study provides useful, actionable guidance to managers on how to create an experience that encourages gamers to engage in real prosumtion in virtual worlds. Firms need to learn about their customers' needs outside of normal exchange processes. By enhancing the previously mentioned perceived benefits, firms can stimulate prosumtion. Also, brand placement may become an important tool of communication with online communities (Fernandes \& Remelhe, 2016, p. 315).

The study findings have several limitations. A lack of quantitative evaluation prevents generalisability beyond theory. Furthermore, the study did not use multiple samples of consumers, such as those engaged and not engaged in the full range of co-creation activities. An interesting statement was noticed, i.e. prosumption is not only advantageous, there are also drawbacks, but that shall also be taken into consideration (like unpaid work of prosumers or idea exploitation for free). The new insights offered by this study suggest that empirical work is needed along the continuum of forms of game modding to further our understanding of the consumer's inclination to participate in game modding as a form of prosumtion. This leaves space for future study.

\section{References}

Agrawal, A. K., \& Rahman, Z. (2015). Roles and Resource Contributions of Customers in Value Cocreation. International Strategic Management Review, 3, 144-160.

Alhashem, M., Moraes, C., \& Szmigin, I. (2013). Collaboration in the marketplace: identifying the critical differences between prosumption and consumer co-creation. In Karaosmanoglu, E., Elmadag Bas, A. (eds.) 42nd Annual Conference, Lost in Translation: Marketing in an Interconnected World. Istanbul, 4-7 June 2013. Istanbul: Istanbul Technical University. pp.149. Available at: 
https://pure.tue.nl/ws/portalfiles/portal/3980803/707265826220161.pdf $\quad$ (accessed 26 May 2020),

Balaji, M.S. (2014). Managing Customer Citizenship Behaviour: a relationship perspective. Journal of Strategic Management, 22(3), 223-239.

Bednarz, J. (2017). Prosumption as a result of changes in consumer behaviour with the example of food industry. Studia Oeconomica Posnaniensia, 5(1), 7-24.

Bettencourt, L. A. (1997). Customer Voluntary Performance: As Partners in Service Delivery. Journal of Retailing, 73(3), 384-386.

Bloch, P. H., Ridgway, N. M., \& Dawson, S.A. (1994). The shopping mall as consumer habitat. Journal of Retailing. 70(1), 23-42.

Bruns, A. (2008). Blogs, Wikipedia, Second Life, and beyond: From production to produsage, New York, NY: Peter Lang.

Chou, T. J., \& Ting, C. C. (2003). The role of flow experience in cyber-game addiction. Cyber Psychology \& Behavior, 6(6), 663-675.

Coyne, I. T. (1997). Sampling in qualitative research. Purposeful and theoretical sampling; merging or clear boundaries? Journal of Advanced Nursing, 26, 623-630.

Dewalska-Opitek, A., \& Mitręga, M. (2019). Appreciate me and I will be your good soldier. The exploration of antecedents to consumer citizenship. Engineering Management in Production and Services, 11(3), 48-59.

Etgar, M. A. (2008). Descriptive Model of the Consumer Co-Production Process. Journal of the Academy of Marketing Science, 1, 97-108.

Fernandes, T., \& Remelhe, P. (2016). How to engage customers in co-creation: customers motivation for collaborative innovations. Journal of Strategic Management, 24(3-4), 311-326.

Fuchs, C. (2013). Digital prosumption labour on social media in the context of the capitalist regime of time. Time \& Society, 23(1), 97-123.

Gephardt, R. (2004). What is qualitative research and why is it important? Academy of Management Journal, 7, $454-462$.

Ghani, J. A., \& Deshpande, S. P. (1994). Task characteristics and the experience of optimal flow in human-computer interaction. The Journal of Psychology: Interdisciplinary and Applied, 128(4), 381-391.

Guest, G., Bunce, A., \& Johnson, L. (2006). How many interviews are enough? An experiment with data saturation and variability. Field Methods, 18(1), 59-82.

Griffiths, M. D., Davies, M. N. O., \& Chappell, D. (2004). Online Computer Gaming: A Comparison of Adolescent and Adult Gamers. Journal of Adolescence, 27, 87-96.

Groth, M. (2005). Customers as Good Soldiers: Examining Citizenship Behaviours in Internet Service Deliveries. Journal of Management, 31(1), 7-27.

Guerro, L. K., Andersen, P. A., \& Afifi, W. A. (2011). Close Encounters: Communication in Relationships. SAGE.

Guido, G., \& Peluso, A. (2008). Preconditions for diffusion of prosumption among firms: a case study approach. Problems and Perspectives in Management, 6(4), 66-73.

Guo, Y., \& Barnes, S. (2011). Purchase behaviour in virtual words: An empirical investigation in Second Life. Information and Management, 48(7), 303-312. 
Henson, R. K., \& Roberts, J. K. (2006). Use of Exploratory Factor Analysis in Published Research Common Errors and Some Comment on Improved Practice. Educational and Psychological Measurement, 66(3), 393-416.

Hinton, S., \& Hjorth, L. (2013). Understanding Social Media, Sage Publications.

Holbrook, M. B. (2006). Consumption experience, customer value, and subjective personal introspection: An illustrative photographic essay. Journal of Business Research, 59, 714-725.

Hong, R., \& Chen, V. H. (2014). Becoming an ideal co-creator: Web materiality and intensive labouring practices in game modding. New Media \& Society, 16(2), 290-305.

Humphreys, A., \& Grayson, K. (2008). The intersecting roles of consumer and producer: a critical perspective on co-production, co-creation and prosumption. Sociology Compass, 2(3), 963-980.

Kim, J. O., Forsythe, S., Gu, Q., \& Moon, S. J. (2002). Cross-cultural consumer values, needs and purchase behaviour. Journal of Consumer marketing, 19 (6), 481-502.

Koo, D. M., Lee, S. H., \& Chang, H. S. (2007). Experimental motives for playing online game. Journal of Convergence Information Technology, 2, 37-48.

Koufaris, M. (2002). Applying the Technology Acceptance Model and Flow theory to Online Consumer Behavior. Information Systems Research. 13(2), 205-223.

Kretzschmar, M., \& Stanfill, M. (2019). Mods as Lightning Rods: A Typology of Video Game Mods, Intellectual Property, and Social Benefit/Harm. Social \& Legal Studies, 28(4), 517-536.

Kücklich, J. (2005). Precarious Playbour: Modders and the Digital Games. Fibreculture, 5, 1-8.

Loh, C. S., \& Byun, J. H. (2009). Modding Neverwinter Nights into serious games. In Digital simulations for improving education: Learning through artificial teaching environments (pp. 408-426). IGI Global.

Miles, M., \& Huberman, A. (1994). Qualitative data analysis. 2nd ed. Thousand Oaks, CA-Sage, p. 27.

Mitręga, M. (2016). System products' concept and presumption. Economic Studies, University of Economics in Katowice, 262, 5-13.

Moon, J. W., \& Kim, Y. G. (2001). Extending the TAM for a World-Wide-Web Context. Information \& Management, 38(4), 217-230.

Morse, J. (1994). Designing funded qualitative research. In Handbook for qualitative research, ed. N. Denzin and Y. Lincoln. Thousand Oaks: CA-Sage, p.129.

Nardi, B., \& Kallinikos, J. (2010). Technology, agency, and community: The case of modding in World of Warcraft, In Industrial informatics design, use and innovation: Perspectives and services. IGI Global, 174-186.

NG Brian, D., \& Wiemer-Hastings, P. (2005). Addiction to the Internet and Online Gaming. Cyber Psychology and Behaviour, 8(2), 110-113.

Payne, A. F., Storbacka, K., \& Frow, P. (2008). Managing the Co-Creation of Value. Journal of the Academy of Marketing Science, 1, 83-96.

Poovey, M. (1995). Making a Social Body, The University of Chicago Press, Chicago, p. 84.

Poretski, L., \& Arazy, O. (2017). Placing value on community co-creations: A study of a video game modding community, In Proceedings of the 2017 ACM Conference on Computer Supported Cooperative Work and Social Computing (2017, February) (pp. 480-491). ACM. 
Poretski, L., Zalmanson, L., \& Arazy, O. (2019). The Effects of Co-Creation and Word-of-Mouth on Content Consumption-Findings from the Video Game Industry, the International Conference on Information Systems (ICIS 2019). December 15-18, 2019, Munich, Germany (pp.1-10).

Postigo, H. (2007). Of mods and modders: Chasing down the value of fan-based digital game modifications. Games and Culture, 2(4), 300-313.

Prahalad, C. K., \& Ramaswamy, V. (2004). Co-Creation Experience: The Next Practice in Value Creation. Journal of Interactive Marketing, 18(3), 5-14.

Roberts, D., Huges, M., \& Kertbo, K. (2013). Exploring consumers' motivations to engage in innovation through co-creation activities. European Journal of Marketing, 48(1/2), 147-169.

Rohm, A. J., \& Swaminathan, V. (2004). A Typology of Online Shoppers Based on Shopping Motivations. Journal of Business Research. 57, 748-757.

Rosenbaum, M. S., \& Messiah, C. A. (2007). When Customers Receive Support from Other Customers. Journal of Service Research, 9(3), 261.

Ross, S. M., \& Kapitan, S. (2018). Balancing self/collective interest: equity theory for prosocial consumption. European Journal of Marketing, 52(3/4), 528-549.

Sandelowski, M. (1995). Sample size in qualitative research. Research in Nursing \& Health, 18(2), 179183.

Scacchi, W. (2011). Modding as a basis for developing game systems, paper presented at 1st Workshop on Games and Software Engineering (GAS'11). at the 33rd International Conference on Software Engineering, May 2011, Waikiki, Honolulu, (available at: https://www.researchgate.net/publication/228743734_Modding_as_a_basis_for_developing_ga me_systems)

Sheth, J. N., Newmann, B. I., \& Gross, B. L. (1991). Why We Buy What We Buy: A Theory of Consumption Values. Journal of Business Research, 22, 159-170.

Steen, M., Manschot, M., \& De Koning, N. (2011). Benefits of co-design in service designed projects. International Journal of Design, 5(2), 53-60.

Terranova, T. (2013). Free labour. In Sholtz, T. (eds). Digital labour. The internet as playground and factory (pp. 33-57). Routledge, New York, and London.

Törhönen, M., Lobna, H., Max, S., \& Juho, H. (2019). Play, Playbour or Labour? The Relationships between Perception of Occupational Activity and Outcomes among Streamers and YouTubers, Proceedings of the 52nd Hawaii International Conference on System Sciences, pp.2558-2567.

Unger, A. (2012). Modding as part of game culture. In Computer Games and New Media Cultures, Springer, Dordrecht, pp. 509-523.

Van Doorn, J., Lemon, K., Mittal, V., Nass, S., Pick, D., Primer, P., \& Verhoef, P. (2010). Customer engagement behaviour. Theoretical foundations and research directions. Journal of Service Research, 13, 253-266.

Vargo, S. L., \& Lusch, R. F. (2004). Evolving to a new dominant logic for marketing. The Journal of Marketing, 68(1), 1-17.

Vargo, S. L., \& Lusch, R. F. (2008). Service-dominant logic: continuing the evolution. Journal of the Academy of Marketing Science, 36(1), 1-10.

Wallace, R. (2014). Modding: Amateur authorship and how the video game industry is actually getting it right. BYU Law Review, 1(7), 219-255. 
Webster, J., Trevino, L., \& Ryan, L. (1993). The dimensionality and correlates of flow in human-computer interactions. Computers in Human Behavior. 9, 411-426.

Wing Sung Tung, V., Chen, P. J., \& Schuckert, M. (2017). Managing customer citizenship behaviour: the moderating roles of employee responsiveness and organisational reassurance. Tourism Management, 59, 23-35.

Wittmayer, J. M., Fraaije, M., Horstink, L., \& Avelino, F. (2019). A multi-dimensional typology of collective RES prosumers across Europe. PROSEU - Prosumers for the Energy Union: Mainstreaming active participation of citizens in the energy transition (Deliverable $\mathrm{N}^{\circ} 2.2$ ). Available at: researchgate.net (accessed 26 May 2020).

Wood, R., Griffiths, M. D., Chappell, D., \& Davies, M. (2004). The Structural Characteristics of Video Games: A Psycho-Structural Analysis. Cyber Psychology and Behavior. 7(1), 1-10.

Wolf, M., \& McQuitty, S. (2011). Understanding the do-it-yourself consumer: DIY motivations and outcomes. AMS review, 1(3-4), 154-170.

Xie, C., Bagozzi, R. P., \& Troye, S. V. (2008). Trying to Prosume: Toward a Theory of Consumers as Co-Creators of Value. Journal of the Academy of Marketing Science, 1, 109-122.

Yi, Y., \& Gong, T. (2006). The ascendants and consequences of service and customer citizenship and badness behaviour. Seoul Journal of Business, 12(2), 145-175.

The research paper passed the review process. | Received: July 1, 2020; Revised: August 18, 2020;

Accepted: August 30, 2020; Pre-published online: December 7, 2020; Published: March 19, 2021. 